\title{
What Do We Know About the Knowledge of Older Workers?
}

\begin{abstract}
In this chapter we give a brief presentation of relevant findings on senior competence and learning abilities from national and international studies. We include studies which have tried to assess the knowledge of older employees, studies which consider the abilities and potential of older employees to continue to develop their knowledge and studies which address the value or advantages of having knowledgeable older employees.
\end{abstract}

Keywords Senior competence - Learning abilities - Knowledgeable older workers

Earlier research on learning and competence in relation to age has been focused on different themes. The themes relevant to the current study are those discussing the knowledge or competence which older employees demonstrate, but we are also interested in studies of the abilities or the potential of older employees to continue to develop this knowledge. The studies we review here are roughly divided into those, which examine the relationship between formal education and the knowledge of older workers, and those studies more interested in learning after the completion of formal education. Lastly, we look at those studies attempting to

(C) The Author(s) 2021 
understand if there is a particular kind of knowledge, which is characteristic of older workers, and attempting to describe the value of such knowledge for employees and employers.

\subsection{Education and the Skills of Older Workers}

Many of the studies on the relationship between age and knowledge have been focused on education and how it affects the abilities and the performance of older workers. The results of large national and international studies on workers are publicly available and one of these is the OECD Programme for the International Assessment of Adult Competencies (PIAAC). This programme studies competence and participation of employees in learning activities in over 40 countries and is carried out every 5 years. The study includes a questionnaire and interviews and a practical assessment of skills in literacy, numeracy and problemsolving. One of the conclusions is that many employees over 55 have fewer years of formal education than their younger colleagues. This is perhaps not so surprising when we think of how the opportunities for education have developed during the last 30 or 40 years and how policymakers have increased their interest in the role of education in our modern societies. The study does find a positive link between higher education or a long formal education and the continued participation of older employees in the workplace. The study found a gradual reduction in the numbers of employees participating in further education or organised training courses at work after the age of 35 , however the opportunity for continued learning throughout working life was found to have positive effect on older workers and their ability to remain active at work. The importance of learning outside formal education, i.e. either practicebased work experience or experience gained outside work was also found to be increasingly important for older employees (OECD, 2016). Practical tests of skills revealed a gradual decline in all skills (literacy, numeracy and problem-solving) from the age of 30 . It has been suggested that adults who continue to use their skills have a lower risk of losing them (OECD, 2016: 3). In many countries, the gap between the skills levels of employees and the requirements of their employment varied and in some countries the gap was much less for older employees, than for their younger colleagues. Although the proficiency of older workers is considered lower (OECD, 2016), their productivity is no lower than younger workers. Qualitative studies have also found that the productivity of older 
workers remains high, although there was variation depending on the workplace. The EU project "Working Life Changes and the Training of Older Workers" (WORKTOW) found a varied situation where older workers were less active in some areas, but participating as actively as their younger colleagues in others (Tikkanen et al., 2002). They found that older employees participated in informal and non-formal training in the same way as younger workers, but to a lesser extent in formal training.

Other studies have provided information on the effects of participation of older adults in some forms of training for improved literacy skills, based on the International Adult Literacy Survey with a Dutch supplement (van der Kamp \& Boudard, 2003). Desjardins and Warnke (2012) have provided an overview of age-skill profiles and potential factors influencing skill gain and skill loss at both individual and population levels. "Although the evidence regarding the age-related decline of cognitive skills is widespread and the explanation that this may be part of 'normal ageing' is intuitively appealing, it is not possible regardless of research design to identify whether ageing effects are caused by neurological maturation effects, behavioural and practice effects, or the interaction of these with contextual effects. Moreover, there is some evidence to suggest that there are several factors that can mitigate, delay or prevent the cognitive decline that is associated with so called 'normal ageing'. Education, training, and a number of physical, social and mental activities have all been implicated as possible factors which help to mitigate the age-related decline in cognitive skills" (ibid.: 55 ).

Some studies have also found evidence of the pressure on older workers to continue learning. An example of this is an analysis of the retirement decision of Norwegian governmental employees, based on survey data (retrospective cohort data), which found that one out of four claimed that their retirement was related to employers' demands for more education (Midtsundstad, 2005). This perceived competence gap is affecting older employees, as shown by Midtsundstad, who found that older employees experiencing a mismatch between actual competence and competence needed to perform current work tasks had a significantly higher probability of leaving the labour market early. 


\subsection{CAN Older Employees LEARN NeW Things AT WORK?}

There are different ways of finding out if older workers are continuing to learn as they age. One can look at how often they participate in formal education or other forms of organised learning. One can also ask managers and younger colleagues about the performance of older employees or one can carry out more explorative studies and find out what older employees actually do at work, and look for examples of learning which the employees or employers may not be aware of. Here we review some studies which attempt to say something about older employees continued learning.

A number of surveys, including in Norway, document that older workers do indeed participate in vocational training, however they participate less frequently than their younger colleagues (Hagen \& Skule, 2001; Skaalvik et al., 2000; Wiborg et al., 2011). The reasons for this are probably many and complex. Some of the explanation is related to the level of education. The general level of education is higher among younger than among older workers, and persons with a high formal education participate more in post- and further education than persons with low formal education. However, even when comparing groups with equal educational attainment, we see that older workers participate less in competence development than those who are younger, even when comparing groups with the same level of education. There must therefore also be other explanations for older people participating less in competence development.

This information on participation in organised adult learning, confirms that there is a potential for older employees to continue their learning after completing their formal education and although there are fewer actively participating in this form of learning, than in younger ages groups, we assume that those who complete courses have learned something from them.

As mentioned in the PIAAC study (OECD, 2016) learning outside formal education is important for older workers, who have perhaps been working for many years, since completing their formal education. Their modern workplaces have probably changed considerably since 55-year-olds left full-time education. Modern workplaces are frequently reorganised, new roles come and go and technology is continuously being 
updated and renewed. If older workers are to remain active at work, they will almost certainly have to learn new things and develop new skills.

A number of studies are interested in the learning that goes on at work and highlight the importance of participation and learning opportunities in the workplace (van den Heuvel et al., 2006). European experiences of lifelong learning and older workers have been studied by Tikkanen and Nyhan (2006). They view ageing as "a lifelong learning and developmental process" (ibid.: 10) and maintain that new challenges at work, which match the employee's interests are necessary to promote continuous learning. Therefore, they conclude that adult learning should be understood broadly including education, training and "participative collective workplace learning". They find that older workers can indeed continue to learn, however this ability will be affected by the kind of workplace they have as well as how employers value the knowledge and experience of older workers and support them in their tasks. The intentions and proactivity, or agency, of the older workers are seen as important if older employees are to continue learning (Billitt \& van Woerkom, 2006).

Some studies have found that opportunities for older employees to learn, are much greater in large organisations and may, as already noted, they can be exposed to a greater degree of training and skills development than in small and medium enterprises (SMEs) (McNair et al., 2004); this might be an important factor determining their ability and willingness to remain active at work. The skills base of older workers, as nurtured by the organisational context, is crucial in developing what Hirsch (2005) refers to as "sustainable working lives". Other studies have found that organisational change is also an important source of learning for employees who have experienced them several times. Fuller and Unwin found that workers who had to adapt to a new situation and a new form of organisation had indeed gained useful insights and developed ways of working which they were able to use again later (Fuller \& Unwin, 2006: 268).

Some studies have found examples of employees who are dealing with change and are indeed learning new skills. A study of opportunities for lifelong learning at work in Norway included some interesting descriptions of what employees and their managers think of seniors and their ability to develop their competence and participate in the workplace (Becken et al., 2015). They found that there were good opportunities for older employees to continue to develop their competence, but in practice, 
it was very much up to the individuals to take the initiative. When it is up to individuals, we see that motivation is important. There were of course examples of many older employees who wanted to prioritise time at home with older partners or with grandchildren, but there were many examples where employees had changed their minds when they found something which motivated them at work.

One example was a nurse who was exhausted and had various ailments due to many years of hard physical work. She had decided to take early retirement as soon as possible. In the meantime, her manager offered her a new position, which was less physically demanding, but challenging in other ways. She was invited to establish a new department responsible for competence development for nurses in the region. This new position required that the nurse had to master new skills, absorb a lot of new information and develop new procedures. She was very unsure about taking the position, but decided to try, and when interviewed she had been doing the new job for some time. She had decided to postpone retirement and carry on working. She said she loved her job, had learned so much and was so glad to have had the opportunity to learn something new, do something different and to take responsibility for something important.

In another example, a public sector employee who found the IT system for registering all his working tasks far too difficult to master and said he was looking forward to retirement and leaving all the bureaucracy behind. Just as the interviewers were leaving, he surprised them by saying there was actually one thing that might make him stay on at work and that was a new IT system for mapping public property. It turned out that this employee was the international super-user for this IT system. He was in frequent contact with the system developers, suggesting changes and improvements to the software and, much to his wife's dismay, accepted calls from users all around the world, offering them help at any time day or night. If he could be allowed to work on this system and not bother with all the bureaucracy, he would definitely consider working a few more years.

These are interesting examples of how older employees might be tempted to withdraw and participate less in certain situations and even retire early. However, in both situations, alternative responsibilities and 
tasks resulted in these employees being stimulated to learn new things and to participate actively. These examples support the findings of the other studies mentioned earlier, that there is a great variety in the type of learning that works for older employees.

\subsection{Senior Competence}

Many authors have written about competence and working knowledge, but fewer have mentioned older workers. Here we consider literature and earlier studies on the competence and working knowledge of older workers and ask if there is such a thing as senior competence. It is not always the seniors themselves, who can say most about their competence, but employers have something to say on the theme, as was found by Bo Göranzon (1990), who carried out research on how employers value the competence of senior workers. He found that some managers are aware of the competence of seniors and judge it to be valuable for their firms. When asked to describe it, they say it is different from the kind of theoretical knowledge, which is easily identifiable in younger employees straight out of schools and universities. Some seniors do have theoretical knowledge, but what most of them have, is a kind of practical knowledge acquired through experience. Göranzon (ibid.) argues that the practical and tacit knowledge of experienced workers is a necessary resource for good productivity. He differentiates between three types of knowledge: Propositional or theoretical knowledge, Skills, or practical knowledge and Knowledge of familiarity. (Göranzon et al., 2006: 192). Whereas theoretical knowledge can be acquired through books, or replaced by computers, skills need practical experience and familiarity is the integrated knowledge developed over time in a community of practice.

Göranzon (1990) makes a point of discussing how computers, or artificial intelligence, may replace some work operations, although basically operations following known rules and theoretical knowledge. As artificial intelligence (AI) develops, this may change as computers are able to acquire skills through repeated performance and feedback. Familiarity takes not only experience over time, but the "knowledge we gain by exchanging experience with colleagues and fellow-workers" (ibid.). Familiarity is social in its being, developed not only through one's own practice but through sharing stories of this experience with others. Familiarity is inspired by Wittgenstein $(1953 / 2001)$ and his claim that a concept gets its meaning through its use, which is in dialogue with others. "The 
meaning of a word is its use in the language" (PI $\$ 43$ ). In On Certainty (Wittgenstein, 1969) elaborates on the social aspect of knowledge. "If experience is the ground of our certainty, then naturally it is past experience. And it isn't for example just my experience, but other's people's, that I get knowledge from" (On Certainty $\$ 275$ ). If this type of knowledge (familiarity) is dependent on taking theoretical knowledge into practice and sharing the emerging knowledge with others, it depends on both experience and time. Even if Wittgenstein does not relate his discussion to age, it is obvious that age and experience are somewhat related. More years, more experience, and therefore more occasions for developing knowledge of all three types.

Göranzon is also primarily concerned with knowledge development, unrelated to age as such. His examples of theoretical knowledge, practical knowledge and familiarity use examples of a boat builder and a photographer (Göranzon, 2006: 13-16) and two cases of forest evaluation and social insurance (Göranzon, 1990). His cases demonstrate how knowledge (skills and familiarity) is developed over time in a community of practice and goes far beyond theoretical knowledge. Göranzon does not specifically use the concept of community of practice, but it is this particularly social aspect of knowledge development that is described in the concept of familiarity.

Community of practice is a concept first proposed by Jean Lave and Etienne Wenger in their book Situated Learning (Lave \& Wenger, 1991). Although they suggested the concept community of practice they are clear that they describe a phenomenon that has existed for as long as people have been learning and sharing their experiences. "Communities of practice are formed by people who engage in a process of collective learning in a shared domain of human endeavour: a tribe learning to survive, a band of artists seeking new forms of expression, a group of engineers working on similar problems, a clique of pupils defining their identity in the school, a network of surgeons exploring novel techniques, a gathering of first-time managers helping each other cope" (Wenger-Trayner, 2015). Community of practice is relevant to the type of learning that depends on working with others, as Göranozon's discussion of skills and familiarity (1990, 2006).

Learning together and developing knowledge that is more extensive than that of the single members of the community makes the concept of familiarity relevant to our discussion of the type of competence developed by older workers through long careers and many years in working life. 
We would expect that workplaces with a mix of older and younger employees would provide opportunities for different age groups to learn from one another. By combing the competence of younger workers with newly acquired theoretical knowledge and the competence of older, experienced workers, we would expect that new combined knowledge might develop. Hilsen and Ennals (2007) describe an example of this process in their study of a good practice model for organisational learning and experience sharing across age divides and distances. The model consisted of both a digital flow chart that described the progress in a field of executive work, as well as a dialogical process of experience sharing. They chose to call the tool "The Golden Link", in recognition of the value of linking seniors, juniors and information technology. The experienced senior gave a detailed and step-by-step description of the progress of a task, while the junior with better computer skills filled out the flow chart. It was developed locally in a Norwegian enterprise facing an increasing number of employees approaching retirement age, and also facing the challenge of how to make the experience-based knowledge and competence of these older workers available to the organisation and to younger colleagues with less experience. Similar examples are found in (Olsen \& Børing, 2019), where employers deliberately used shadowing techniques to transfer knowledge from seniors to juniors. The model was a tool not only to support cross-generational communication and learning, but also to enable access for mobile workers to the knowledge of experienced seniors not physically present.

The ability to use new technology at work is becoming increasingly important in the modern workplace and this prompts the question of whether older workers actually have more or less digital competence than their younger colleagues. Attitudes towards older workers strongly suggest that they are perceived as less competent than younger colleagues (OsloEconomics, 2018: 44). If they are seen as less competent, they may be challenged less frequently, given fewer opportunities to develop skills or even be excused from mastering the new tools. Also there are huge individual differences, based on (among others) personality, exposure to technology and type of work. Even if younger people are more comfortable with digital technology, this may be a cohort phenomenon rather than a result of ageing. Growing up in a digital world gives a different experience than being introduced to it as grown-ups, as exemplified in Tapscott's (1998, 2009) concept of the Net Generation or Prensky's 
(2001) concept of Digital Natives and Digital Immigrants. This would imply that when the Net Generation grows older, they will continue to be comfortable with the technology. Experience with the tasks to be carried out might also compensate for unfamiliarity with the digital tools to be used.

A recent study (Soja \& Soja, 2020) on getting older employees to use ICT in an efficient way included an overview of the advantages of older employees (in this case over 50). Their paper is based on a review of literature on older employees and ICT and 187 interviews with employees involved in the recent implementation of ICT systems. Some of these advantages were related to loyalty and lower absenteeism, however most of them were related to skills or knowledge based on long experience. Some of these advantages were:

- Know-how and experience, ability to comprehend the whole

- Awareness of one's own limitations and strong points, selfconfidence

- Greater soft skills (e.g. interpersonal skills)

- Reason in solving problems

- Reason in dealing with co-workers and clients (Soja \& Soja, 2020: 411).

The authors conclude that older employees have the potential to develop skills which they see as being complementary to ICT and as such these skills could be very valuable in a technology-rich environment. They mention skills such as communication with co-workers and clients, problem-solving and the ability to develop good plans. Activities relating to planning and implementing ICT systems are all enhanced when older employees with their advanced interpersonal skills use their ability to facilitate adaptation (ibid.: 427).

Age differences and learning abilities in a work life context is a complex phenomenon and needs to be addressed in a contextual way (Lahn, 2003: 130). Even psychological tests (such as IQ tests or the Rorschach test) show individual differentiated results. A Norwegian longitudinal study followed a group of 100 individuals from the age of 13 in 1939 into their 70s with repeated tests at the age of 13,58 and 68 years of age (Seim, 1988, 1997 in Daatland \& Solem, 2011: 77). Some individuals 
scored higher with age, others lower, some personal traits differed, but also differed between individuals of the same age.

In a review of the literature on cognitive ageing and learning abilities in an occupational context, Lahn (2003) claims that "multidimensional and non-linear perspectives are increasingly replacing models of late career as a period of declining expertise" (ibid.: 126). This is supported by the results from the WORKTOW project. Age seems to be a poor predictor of performance, both personal performance and work performance (Lahn, 2003: 128; OsloEconomics, 2018: 28).

In spite of age being a poor predictor of performance at the individual level, there are studies that relate performance to age at an aggregated level. A study using meta-analytic techniques (number of samples $=92$ ) to determine the patterns of mean-level change in personality traits across the life course on personality and age uses the personality test The Big Five. This test measures scores on five major dimensions of personality: Openness, Conscientiousness, Extraversion, Agreeableness and Neuroticism. The study concludes that as one ages, Neuroticism is reduced and so is Extraversion, Agreeableness and Conscientiousness increases and Openness rises early in life but declines with age (OsloEconomics, 2018: 34; Roberts et al., 2006). As we shall see from our interviewees who talk about different approaches to work as they age, and the personality traits from the Big Five may be relevant in discussion of such changes.

Like the PIAAC findings mentioned earlier, Solem also finds in this review that there is "no general decline in work performance with age" (Solem, 2007: 32), mainly because of individual differences in the effect of ageing. Solem quotes the gerontologist Dannefer (2003 in Solem, 2007: 15) who has called this process of increased individual differences «cumulative advantage/disadvantage». As one grows older, age is only one factor that influences work performance, alongside a wide range of other individual and institutional factors.

To summarise, we can say that there is evidence that employees over 50 do indeed continue to participate in formal education and organised courses, however they do this to a lesser extent than their younger colleagues. With regard to informal learning there are also examples where employees have either chosen, been encouraged or even forced to learn new skills, to master new ways of working or to deepen their understanding in order to keep their jobs or meet the challenges presented at work. The few researchers who have broached the theme of the elusive senior competence have mentioned various nuances such as familiarity 
(Göranzon, 2006) and soft skills linked to implementing new technologies (Soja \& Soja, 2020). This leaves us with some unanswered questions such as why do fewer older employees participate in formal training and organised courses? Several of the studies reviewed so far have mentioned the importance of informal learning, why do we know so little about the informal learning of older employees at work? Lastly is the issue of the value of this senior competence; the studies presented here suggest that management decisions vary greatly and that many may be based on long-held beliefs about older employees or old age in general. We will attempt to shed some light on some of these questions later, but in the next chapter we will present our methods for gathering and analysing our empirical data from older employees at work.

\section{REFERENCES}

Becken, L. E., Carlsten, T. C., Børing, P., Wedde, E., Olsen, D. S., \& Berg, H. (2015). Livslang laring og ansettbarbet for arbeidstakere over 55 àr. [Lifelong learning and employability among employees 50+]. Proba samfunnsanalyse.

Billett, S., \& van Woerkom, M. (2006). Older workers and learning through work: The need for agency and critical reflection. In Tikkanen, T., \& Nyhan, B. (Eds.), Promoting lifelong learning for older workers: An international overview (pp. 177-189). Office for official Publications of the European Communities.

Daatland, S. O., \& Solem, P. E. (2011). Aldring og samfunn (2.ed.). Fagbokforlaget.

Dannefer, D. (2003). Cumulative Advantage/Disadvantage and the Life Course: Cross-Fertilizing Age and Social Science Theory. The Journals of Gerontology: Series B, 58(6), November 2003, Pages S327-S337. https://doi.org/10. 1093 /geronb/58.6.S327.

Desjardins, R., \& Warnke, A. (2012). Ageing and skills: A review and analysis of skill gain and skill loss over the lifespan and over time. OECD Education Working Papers, No. 72. Paris: OECD Publishing. https://doi.org/10. $1787 / 5 \mathrm{k} 9$ csvw $87 \mathrm{ckh}-\mathrm{en}$.

Fuller, A., \& Unwin, L. (2006). Older workers' learning in changing workplace contexts: barriers and opportunities. In T. Tikkanen \& B. Nyhan (Eds.), Promoting lifelong learning for older workers: An international overview (pp. 258-270). Office for Official Publications of the European Communities.

Göranzon, B., Hammarén, M., \& Ennals, R. (Eds.). (2006). Dialogue, skill and tacit knowledge. John Wiley.

Göranzon, B. (1990). Det praktiska intellektet. Carlsson Bokförlag. 
Hagen, A., \& Skule, S. (2001). Yrke, opplaringsbehov og interesse for etter- og videreutdanning. Fafo-rapport 372.

Hagen, A., og Skule, S. (2007). Den norske modellen og utviklingen av kunnskapssamfunnet. In I. Dølvik, J. E. m.fl. (red.), Hamskifte. Den norske modellen $i$ endring (s. 145-168). Gyldendal Norsk Forlag.

Hilsen, A. I., \& Ennals, R. (2007). Virtual links: Intergenerational learning and experience sharing across age divides and distances. In AI \& Society. https:// doi.org/10.1007/s00146-007-0166-6 (published before print).

Hirsch, D. (2005). Sustaining working lives: A framework for policy and practice. Joseph Rowntree Foundation.

Lahn, L. Ch. (2003). Competence and learning in late career. European Educational Research Journal, 2(1), 126-140.

Lave, J., \& Wenger, E. (1991). Situated learning: Legitmate peripheral participation. Cambridge.

McNair, S., Flynn, M., Owen, L., Humphreys, C., \& Woodfield, S. (2004). Changing work in later life: A study of job transitions. University of Surrey, Centre for Research into the Older Workforce.

Midtsundstad, T. (2005). Ikke nødvendigvis sliten... En analyse av tidligpensjonering og seniorpolitikk $i$ staten. Fafo-report 482. Oslo: Fafo.

OECD. (2016). The survey of adult skills. Reader's companion (2nd ed). OECD Skills Studies. OECD Publishing. https://doi.org/10.1787/978926425807 5 -en.

Olsen, D., \& Børing, P. (2019). Kompetanseutvikling og livslang læring blant seniorer innenfor akademikeryrker. NIFU Report, 2019, 14.

OsloEconomics. (2018). Aldringens betydning for helse, arbeidskapasitet og arbeidsprestasjoner. Rapport utarbeidet på oppdrag fra Senter for seniorpolitikk. 2018_32. Oslo: OsloEconomics.

Prensky, M. (2001). Digital natives, digital immigrants. On the Horizon, 9(5), $1-6$.

Roberts, B. W., Walton, K. E., \& Viechtbauer, W. (2006). Patterns of meanlevel change in personality traits across the life course: A meta-analysis of longitudinal studies. Psychological Bulletin, 132(1), 1-25.

Skaalvik, E. M. m.fl. (2000). Voksenopplering $i$ Norge ved tusenairsskiftet. Deltakelse, motivasjon og barriever. Norsk voksenpedagogisk forskningsinstitutt.

Soja, E., \& Soja, P. (2020). Fostering ICT use by older workers: Lessons from perceptions of barriers to enterprise system adoption. Journal of Enterprise Information Management, 2(33), 407-434.

Solem, P. E. (2007). Seniorer i arbeidslivet. Kunnskap om aldring og arbeid. Norsk institutt for forskning om oppvekst, velferd og aldring. NOVA Rapport 16/2007. Oslo: NOVA. 
Tapscott, D. (1998). Growing up digital: The rise of the net generation. McGrawHill.

Tapscott, D. (2009). Grown up digital: How the net generation is changing your world. McGraw-Hill.

Tikkanen, T. Lahn, L. C., Withnall, A., Ward, P., \& Lyng, K. (2002). Working life changes and training of older workers. Research Report. VOX \& European Commission ISBN: 82-7724-039-2.

Tikkanen, T., \& Nyhan, B (Eds.). (2006). Promoting lifelong learning for older workers: An international overview. Cedefop Reference series. Luxembourg: Office for Official Publications of the European Communities.

van der Kamp, M., \& Boudard, E. (2003). Literacy proficiency of older adults. International Journal of Educational Research, 39(3), 253-263.

Van den Heuvel, J. (2006). Board roles in small and medium-sized family businesses: Performance and importance. Corporate Governance, 14(5), 467-485.

Wenger-Trayner, E. \& B. (2015). Introduction to communities of practice: A brief overview of the concept and its uses. https://wenger-trayner.com/introductionto-communities-of-practice/.

Wiborg, Ø., Sandven, T., \& Skule, S. (2011). Livslang laring $i$ norsk arbeidsliv 2003-2010. Trender og resultater fra Lærevilkårsmonitoren. NIFU Rapport $5 / 2011$.

Wittgenstein, L. (1953/2001). Philosophical investigations. The German Text with a Revised English Translation. Blackwell.

Wittgenstein, L. (1969). On certainty (Uber Gewissheit). In G. E. M. Anscombe \& G. H. von Wright (Eds.). Translated by Denis Paul and G. E. M. Anscombe. Basil Blackwell, 1969-1975. http://budni.by.ru/oncertainty. html. 
Open Access This chapter is licensed under the terms of the Creative Commons Attribution 4.0 International License (http://creativecommons.org/licenses/ by $/ 4.0 /$ ), which permits use, sharing, adaptation, distribution and reproduction in any medium or format, as long as you give appropriate credit to the original author(s) and the source, provide a link to the Creative Commons license and indicate if changes were made.

The images or other third party material in this chapter are included in the chapter's Creative Commons license, unless indicated otherwise in a credit line to the material. If material is not included in the chapter's Creative Commons license and your intended use is not permitted by statutory regulation or exceeds the permitted use, you will need to obtain permission directly from the copyright holder.

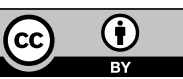

